\title{
Cerebral Concussions and Football
}

\author{
Jack Kushner* \\ George Washington University, USA \\ Submission: February 02, 2018; Published: February 12, 2018 \\ *Corresponding author: Jack Kushner, George Washington University, USA, Email: jkaoportal@comcast.net
}

Abstract

The definition of cerebral concussion is reviewed and the management of athletes suffering with a cerebral concussion is discussed.

Keywords: Cerebral concussion; Traumatic brain injury

\section{Introduction}

After recently participating in a radio panel discussion about cerebral concussions and football, it became apparent to me that there is the need to review some of the accepted information now available about this important subject. First, it is essential that we define exactly what is meant when discussing concussions incurred during athletic events. "Cerebral concussion or traumatic brain injury is a clinical syndrome characterized by immediate and transient post-traumatic impairment in neural function, such as alteration of consciousness, disturbance of vision, equilibrium, due to brain stem involvement" [1]. This is the definition recommended by the Ad Hoc Committee to Study Head Injury of the Congress of Neurological Surgeons. Modifications to this definition have been made by various researchers and clinicians. For example, Cantu incorporated posttraumatic amnesia into the definition [2]. Torg identified four levels of consciousness due to head trauma. He defined a mild head injury as having confusion and disorientation but without any amnesia, and classic cerebral concussion as having both retrograde and posttraumatic amnesia. He described a concussion as "phenomenon of physiological neurological dysfunction with no anatomic disruption [3]. Others have argued that a concussion may or may not be associated with a loss of consciousness, but maintain that confusion and amnesia are the major components of concussion and do influence any decisions about the athlete's returning to the football field. Additional symptoms of a concussion may include memory problems, drowsiness, dizziness, blurred vision, headache, nausea and vomiting, sensitivity to light and noise, balance problems, and a reduced reaction time to stimuli. It is important that the athlete not return to the football game if he has any of these residual symptoms.

Numerous studies of cerebral concussions have demonstrated some metabolic changes $[4,5]$. Briefly, some of the studies show that there is an increase in the extracellular potassium concentrations after concussion, which last about 4 minutes in some of the brain areas. There is also an increase in the metabolism of the brain, which results in an increase in glucose utilization. Afterwards, there is a period of decreased cerebral metabolism, and the brain cells become susceptible to death if there is a second injury even though the injury may be milder.

Now the question arises as to what should be done once the diagnosis has been made. What is the best management for these athletes? During the recovery period, the patient may experience irritability, sensitivity to light or noise, difficulty concentrating, and mild headaches. In some cases the patient could have balance issues, loss of coordination, problems walking, seizures, unequal pupil size, and drainage of clear fluid from the ears or nose, and slurred speech. If there is no loss of consciousness and the symptoms resolve in less than 15 minutes and the sideline assessments are normal, then the football player can return to the game. If, on the other hand, the symptoms last more than 15 minutes, the patient should not return to the game and should be held back for at least one week. If there is any loss of consciousness and depending on its length, the patient should not return to playing football for a greater period of time. The timing for return to school and to competition vary from patient to patient and this depends on the patient's individual course. If the unconsciousness lasts more than 5 minutes, the patient should be hospitalized and treated as having a severe head injury with appropriate testing.

What exactly is the role of neuropsychological testing? This is a useful tool to obtain important data concerning the extent of cerebral concussion. There are many tests, but most of them test one or many aspects of orientation, post-traumatic amnesia, verbal memory, visual scanning, mental flexibility, word fluency, attention span, coordination, and motor speed. Some professional 
football teams do these exams prior to the beginning of the season and then compare these tests with exams during the season and afterwards. Because of the expense and the time involved, many colleges and high schools only run these tests on as needto-know basis [6]. What are the after-effects of a single cerebral concussion vs. repetitive cerebral concussions? If a single cerebral concussion is severe and of long duration, that could be just as serious as repetititve cerebral concussions. Studies have demonstrated that traumatic brain injury is a potential risk factor for the occurrence of neurodegenerative dementing disorders. This includes Alzheimer's and Parkinson's diseases, as well as clinical depression. A 10- fold increase has been reported in the risk of developing Alzheimer's disease in those patients who have the ApoE e4 gene and a history of traumatic brain injury compared with only a two- fold increase in the risk with the ApoE e4 gene alone [7]. The neuropathological findings in a brain that had a traumatic injury include redutions in synaptic density, loss of neurons, granulovacuolar degeneration, possibly senile plaques, and neurofibrillary tangles [8]. Another aspect of cerebral concussion that should be considered is the issue of very young children playing football. Injuries during adolescence are common and these can occur when the child's brain is still growing and maturing. The World Health Organization defines these children as being between the ages 10-19, and states that brain injuries in this group may have poorer outcomes than older athletes. For children over 12, there is a Sports Concussion Assessment Tool (Scat 3) which demonstrates that these concussions may result in neuropathological findings such as axonal injury, microbleeds, and glial activation. This will provide a source of biomarkers, which may be later useful in detecting pathology, establishing baseline physiology, and tracking recovery afterwards. Finally, the management of athletes who have experienced a cerebral concussion requires decisions for both adolescents and older players regarding when they can return to play or return to school. Although guidelines and position statements have been made by numerous reliable groups, the fact is that there is no empirical evidence based on physiological data to support these guidelines [9-11]. There is agreement that all players who have a cerebral concussion must be removed from the playing field and should not return until the symptoms have resolved. The decision to return to play takes into account the fact that one cerebral concussion can make the player more susceptible to another injury and that repeated injuries in a short period of time can result in cumulative neuropathology.

Some patients who have experienced persistent dizziness and balance deficits might benefit by having vestibular rehabilitation. This therapy focuses on restoring the vestibular system's ability to detect head motion and postural control and stability [12]. Depending on the extent of the vestibular dysfunction, there are three principle methods of exercise that can be prescribed: 1) habituation 2) gaze stabilization, and 3) balance training. The habituation exercise reduces the dizziness by repeated exposure to specific movements or visual stimuli. The gaze stabilization is used to improve the control of the eye movements. And the balance training is used to reduce the fall risk [13].

\section{Conclusion}

Understanding the definition and management of cerebral concussion is necessary when making decisions concerning athletes who play football. It is important for all to recognize that cerebral concussions should be taken seriously and all efforts should be made to play football safely.

\section{References}

1. (1996) Ad Hoc Committee to Study Head Injury Nomenclature: Proceedings of the Congress of Neurological Surgeons in 1964. Clin Neurosurg 46: 386-394.

2. Cantu RC (1986) Guidelines for return to contact sports after a cerebral concussion. Phys Sportsmed 14(10): 755-783.

3. Torg JS (1991) Intracranial injuries. In Torg JS (ed) Athletic Injuries to the Head, Neck, and Face. St. Louis, Mosby-Year Book, USA, pp. 272-274

4. Katayama Y, Becker D, Tamura T, Hovda D (1990) Massive increases in extrcellular potassium and the indiscriminate release of glutamate following concussive brain injury. J Neurosurg 73(6): 889-900.

5. Kawamata T, Katayama Y, Hovda D, Yoshino A, Becker D (1992) Administration of excitatory amino acid antagonists via microdialysis attenuates the increase in glucose utilization seen following concussive brain injury. J Cereb Blood Flow Metab 12(1): 12-24.

6. Maroon JC, Lovell MR, Norwig J, Podell K, Powell JW, et al. (2000) Cerebral concussion in athletes: Evaluation and neuropsychological testing. Neurosurgery 47(3): 659-672.

7. Guskiewicz KM, Marshall SW, Bailes J, McCrea M, Cantu RC, et al. (2005) Association between recurrent concussion and late-life cognitive impairment in retired professional football players. Neurosurgery 57(4): 719-726.

8. Mayeux R, Ottman R, Maestre G, Ngai C, Tang MX, et al. (1995) Synergistic effects of traumatic head injury and apolipoprotein-epsilon 4 in patients with Alzheimer's disease. Neurology 45(3): 555-557.

9. Graham R, Rivara FP, Ford MA, Spicer CM (2014) Sports-related concussions in youth: improving the science, changing the culture. Institute of Medicine and National Research Council. The National Academies L Press, Washington, USA.

10. McCrory P, Meeuwisse W, Aubry M, Cantu B, Dvorák J, et al. (2013) Consensus statement on concussion in sport-the $4^{\text {th }}$ international conference on concussion in sport held in Zurich. Br J Sports Med 47(5): 89-117.

11. Davis GA, Iverson Gl, Guskiewicz KM, Ptito A, Johnston KM, et al. (2009) Contributions of neuroimaging, balance testing, electrophysiology and blood markers to the assessment of sport-related concussion. $\mathrm{Br} \mathrm{J}$ Sports Med 43(1): i36-i45.

12. Han BI, Song HS, Kim JS (2011) Vestibular rehabilitation therapy: review of indications, mechanisms, and key exercises. J Clin Neurol 7(4): 184-196.

13. https://vestibular.org/ 
(C) This work is licensed under Creative CC) Commons Attribution 4.0 License BY DOI: 10.19080/JOJNHC.2018.06.555685
Your next submission with Juniper Publishers will reach you the below assets

- Quality Editorial service

- Swift Peer Review

- Reprints availability

- E-prints Service

- Manuscript Podcast for convenient understanding

- Global attainment for your research

- Manuscript accessibility in different formats

( Pdf, E-pub, Full Text, Audio)

- Unceasing customer service

Track the below URL for one-step submission https://juniperpublishers.com/online-submission.php 